\title{
АРХЕОЛОГІЯ
}

УДК [572.087 : 903.5] (477) «637»

DOI: https://doi.org/10.33782/eminak2020.3(31).433

\section{КРАНІОСКОПІЧНА ХАРАКТЕРИСТИКА НОСІЇВ ЯМНОЇ ТА КАТАКОМБНОЇ КУЛЬТУР УКРАЇНИ}

\author{
Юрій Долженко \\ Інститут археології Національної академії наук України (Київ, Україна) \\ e-mail: yuriy_dolzhenko@ukr.net \\ ORCID: https://orcid.org/0000-0001-9807-2835
}

У статті розглядаються дискретно-варіативні ознаки на черепі людини носіїв ранньої та середньої бронзи (ямної й катакомбної культури) з території сучасної України. Автор опрацював 253 черепи з території України (епоха ранньої та середньої бронзи) за даними етнічної краніоскопії. Після багатомірного аналізу методом головних компонент і кластерного аналізу, за даними етнічної краніоскопії виявлено значну подібність ямної та катакомбної культур з території Украӥни.

Ключові слова: ямна культура, катакомбна культура, поховання, череп, краніоскопія

Розв’язання проблеми етнічної історії давнього населення України, зокрема антропологічного складу певних племінних об'єднань, з'ясування питань, пов'язаних з формуванням давніх рас та антропологічних типів, стоять у центрі уваги українських антропологів не перший рік. Кісткові останки, у даному разі, єдиний переконливий доказ того, що в окремий археологічний період на певній території був поширений саме такий, а не інший антропологічний тип. Окрім того, вивчення краніологічних об'єктів дає змогу з'ясувати відношення спорідненості між антропологічними типами, скласти уявлення про їх фізичний вигляд, встановити давність, місце та передумови походження ${ }^{\text {. }}$

3 епохою бронзи пов'язані інтенсивні переміщення племен, які почалися ще у мезоліті². Щодо походження ямної культури Нижньої Наддніпрянщини українські археологи дотримуються двох версій. Перші вважають, що ямна культура виникла на місцевій основі, зазнавши значного впливу південно-східних енеолітичних культур 3 . Інші - пов'язують появу ямної культури з прийшлим новим населенням з південно-

\footnotetext{
1 Зіневич Г.П., Круц С.І. Антропологічна характеристика давнього населення території України (за матеріалами експедицій 1961-1963рр.). Київ: Наукова думка,1968. С. 3.

2 Круц С.И. Население территории Украины эпохи меди-бронзы (по антропологическим данным). Киев: Наукова думка,1972. С. 3.

3 Телегін Д.Я. Василівський третій некрополь в Надпоріжжі // Археологія. 1961. Вип. XIII. С. 3-19; Шапошникова О.Г. Поселения ямной культуры на Нижнем Поднепровье. Автореф. дис... канд. ист. наук. Москва, 1962.16 с.
} 
го сходу4 Проблему походження катакомбної культури порушували різні дослідники. Так А.П. Круглов і В.П. Подгаєцький 5 , а за ними 0.0. Кривцова-Гракова6 і Т.Б. Попова7 $^{7}$ відстоювали автохтонну гіпотезу походження катакомбної культури, пояснюючи її появу поступовим розвитком ямної. Спростування автохтонної гіпотези почалося з відгуку С.С. Березанської й О.Г. Шапошникової8 на монографію Т.Б. Попової9, присвячену катакомбній культурі. Поступово було виділено локальні варіанти цієї культури й питання про походження почали порушувати окремо до кожного з них. Гостро розкритикувавши позицію 0.О. Кравцової-Гракової і Т.Б. Попової, Л.С. Клейн10 запропонував своє бачення цього питання. На його думку, донецька катакомбна культура походила від культури поодиноких поховань із Данії.

За масштабністю ямна спільнота не мала аналогів у світовій системі культур доби бронзи. Вона об'єднувала пам'ятки ямної та буджацької культури, що відносяться до періоду раннього бронзового віку, за усним повідомленням Р.О. Литвиненка11, після аналізу (C14 хронологія) датується XXXII-XXVIII ст. до н. е. Назва ямної спільноти походить від типу поховальних споруд - прямокутних ям, перекритих могильним насипом ${ }^{12}$. Катакомбна спільнота, також за усним повідомленням Р.О.Литвиненко (XXVII-XXIII ст. до н. е.), була поширена у степовій і лісостеповій смузі від Приуралля та Північного Кавказу до пониззя Дунаю й репрезентована численними похованнями, десятками поселень і кількома скарбами бронзових речей 13.

У нашому дослідженні, за даними Г.П. Зіневич і С.I. Круц, давньоямні поховання датуються кінцем III, або навіть початком II тис. до н. е. ${ }^{14}$ Але ці дані після хронологічних досліджень на C14 уже застарілі15. Переважно покійників ховали у прямо-

\footnotetext{
4 Даниленко В.Н. Археологические исследования 1956 года в Чигиринском районе // Краткие сообщения Института археологии Академии наук УССР. 1959. Вып. 8. С. 13-21; Даниленко В.Н. Неолит Украины: Главы древней истории Юго-Восточной Европы. Киев: Наукова думка, 1969. 257 с.; Даниленко В.Н. Энеолит Украины: Этноисторическое исследование. Киев: Наукова думка, 1974. 176 с.; Зиневич Г.П. Очерки палеоантропологии Украины. Киев: Наукова думка, 1967. 239 с.

5 Круглов А.П., Подгаецкий Г.В. Родовое общество степей Восточной Европы // Известия Государственной академии истории материальной культуры. Вып. 119. 1935. 176 с.

${ }^{6}$ Кривцова-Гракова О.А. Погребения бронзового века и предскифского времени на Никопольском курганном поле // Материалы и исследования по археологии СССР: Памятники скифосарматской культуры. Москва, 1962. Т. 115. С. 5-55.

7 Попова Т.Б. Племена катакомбной культуры. Москва: Госкультпросветиздат, 1955 (Труды Государственного исторического музея. Вып. 24). С. 41-47.

8 Березанская С.С., Шапошникова О.Г. Рецензия на книгу Т.Б. Поповой «Племена катакомбной культуры» // Советская археология. 1957. № 2. С. 38.

9 Попова Т.Б. Указ. раб. 180 с.

10 Клейн Л.С. К проверке оснований гипотезы о генетической связи ямной и катакомбной культур // Советская археология. 1970. № 1. С. 49-57; Клейн Л.С. Катакомбные памятники эпохи бронзы и проблема выделения археологических культур // Советская археология. 1962. № 2. С. 38; Клейн Л.С. О так называемых ямных погребениях катакомбного типа // Советская археология. 1961. № 2; Клейн Л.С. Происхождение донецкой катакомбной культуры: Автореф. дис... к. и. н. Ленинград, 1968.

11 Литвиненко Р.О. Генеза, розвиток та історична доля культурного кола Бабине // Матеріали та дослідження з археології Східної України. Луганськ: Вид-во СНУ, 2009. № 9. С. 44-90.

12 Археологія України. Курс лекцій / ред. Л.Л. Залізняк. Київ: Либідь, 2005. С. 143.

13 Археологія України ... С. 156.

14 Зіневич Г.П., Круц С.І. Антропологічна характеристика... С. 33.

15 Литвиненко Р.А. Культура Бабино (многоваликовой керамики) и проблемы бронзового века бассейна Дона // Археологические памятники Восточной Европы. Воронеж: Изд-во ВГПУ, 2002. C. 76-85; Литвиненко Р.О.ББабинські культури Українського Лівобережного Лісостепу // Українська археологія: здобутки, сучасний стан та перспективи. Суми, 2019. С. 195-198.
} 
кутних або ж овальних (значно рідше) ямах. Іноді ями перекривали дерев'яним накатником, шаром камки (морська трава) або навіть вапняковими плитами. Поховання зазвичай поодинокі. Покійника клали на спині з підігнутими ногами, які пізніше падали вбік (іноді трапляються поховання, скорчені на боці), головою на схід або на північний чи на південний схід. Поховальний інвентар бідний, одноманітний 16.

За даними С.П. Сегеди ${ }^{17}$, протягом IX-X ст. до н. е. на території Приазов’я, Лівобережжя, а згодом і Правобережжя, включаючи лісостепову зону, поширилися племена катакомбної культури, принаймні частина яких належала до індоаріїв. Населення її раннього та пізнього етапу істотно розрізнялося між собою за антропологічним типом ${ }^{18}$. Катакомбні племена ховали покійників у катакомбах або ж підбоях і дуже рідко - в простих ямах. Орієнтація також різна, частіше південна з відхиленням до заходу або сходу. Трапляються випадки трупоспалення у катакомбах і кенотафи. Як і в ямний час, покійників посипали червоною вохрою. Поховальний інвентар різноманітний.

Зміна культури попервах не супроводжувалася зміною населення. На це вказують спостереження антропологів ${ }^{19}$ й особливості матеріальної культури, насиченої ще «ямними» рисами. За даними археологів ${ }^{20}$, населення ямної культури через зміну ідеологічної (релігійної) парадигми поступово переходило до ритуалу поховання у катакомбах 21.

Як зазначала М.М. Герасимова 22 , краніологічний матеріал носіїв ямної культури найкраще досліджений з території України ${ }^{23}$. Але, незважаючи на окремі успіхи у вивченні краніологічних серій, проблема етнічного складу давніх мешканців України залишається найактуальнішою і потребує найширших антропологічних досліджень. Зокрема, дослідження з краніоскопії на сьогодні вкрай фрагментарні 24 .

Краніологічну серію ямної культури (кінець III тис. до н. е.) лісостепової смуги 3

\footnotetext{
16 Зіневич Г.П., Круц С.І. Антропологічна характеристика... С. 33.

17 Сегеда С.П. Антропологічний склад українського народу: етногенетичний аспект. Київ: Либідь, 2001. C. 156.

18 Сегеда С.П. Антропологічний склад... С. 156; Круц С.И. Позднетрипольские памятники Среднего Поднепровья. Киев, 1977. С. 33.

19 Круц С. И. Позднетрипольские памятники... С. 33.

20 Археологія України... С. 157.

21 Братченко С.Н. Донецька катакомбна культура раннього етапу. Ч. 1. Доба бронзи. Луганськ: Шлях, 2001. 75 с.; Братченко С.Н. Донецька катакомбна культура раннього етапу. Ч. 2. Доба бронзи. Луганськ: Шлях, 2001. 124 с.

22 Герасимова М.М. К вопросу о происхождении ямной культуры // Вестник антропологии. Вып. 19. 2011. С. 104-111.

23 Зиневич Г.П. Очерки палеоантропологии Украины...; Зіневич Г.П., Круц С.I. Антропологічна характеристика... 144 с.; Кондукторова Т.С. Антропология населения Украины мезолита, неолита и эпохи бронзы. Москва, 1973. 127 с.; Круц С.И. Население территории... 192 с.; Круц С.И. Палеоантропологические исследования Степного Поднепровья (эпоха бронзы). Киев: Наукова думка, 1984. $325 \mathrm{c}$.

24 Громов А.В. Антропология населения окуневской культуры Южной Сибири: Эпоха бронзы. Дис... к. и. н. 03.00.14. - Антропология. Санкт-Петербург, 2002; Казарницкий А.А. Население эпохи бронзы в степях Северо-Западного Прикаспия // Записки Института истории материальной культуры. 2011. № 6. С. 133-142; Козинцев А.Г. Этническая краниоскопия и расовая изменчивость швов черепа современного человека. Ленинград: Наука, 1988.
} 
могильника біля с. Баштечки 25 Тальнівського р-ну Черкаської обл. за етнічною одонтологією досліджував С.П.Сегеда ${ }^{26}$. За даними антрополога, вона характеризується типовим середньоєвропейським поєднанням ознак, що склалися на основі одонтологічних комплексів неолітичної людності України, а саме: помірною частотою лопатоподібних форм верхніх медіальних різців, середнім рівнем редукції першого нижнього моляра, відсутністю дистального гребеня тригоніда та невисоким відсотком колінчастої складки метаконіда27. За одонтологічною програмою краніологічну серію ямної культури (кінець III тис. до н. е.) Нижньої Наддніпрянщини з могильника Орджонікідзе ${ }^{28}$ Нікопольського р-ну Дніпропетровської обл. опрацював С.П. Сегеда ${ }^{29}$. Дослідник відзначив наявність певного компонента південного грацильного одонтологічного типу на черепах із курганів Нижньої Наддніпрянщини та в збірній серії черепів із курганів Північно-Західного Причорномор'я ${ }^{30}$.

Програма та методика. У палеоантропологічних реконструкціях переважно використовують краніометричну програму 31 , а також етнічну одонтологію32. Краніоскопічну методику розробив російський антрополог О.Г. Козінцев 33 , який подав її у завершеному варіанті 1992 р. ${ }^{34}$ Відтоді в антропологічній науці, завдяки великій кількості порівняльного матеріалу, стало можливо використовувати краніоскопічні ознаки в етногенетичних і расових дослідженнях. Це дуже важливо для встановлення походження і контактів палеопопуляцій. Краніоскопічні ознаки майже незалежні від краніометричних, тож постають окремим джерелом інформації про взаємозв'язки досліджуваних груп. Ознаки, які вивчив О.Г. Козінцев, ста-

\footnotetext{
25 Артеменко И.И. Культуры позднего бронзового века южной полосы лесов Европейской части СССР: сосницкая культура, комаровская культура, бондарихинская культура // Эпоха бронзы лесной полосы СССР. Москва, 1987. С. 106-118 (Археология СССР); Артеменко I.I. Основні підсумки і завдання археологічних досліджень в Українській РСР // Археологія. 1978. Вип. 26. С. 3-20.

${ }_{26}$ Сегеда С.П. Антропологічний склад... С. 43, Табл. 2.1; С. 154-155.

27 Ibidem.

28 Мозолевский Б.Н. Скифские курганы в окрестностях г. Орджоникидзе на Днепропетровщине // Скифия и Кавказ. Киев: Наукова думка, 1980.

29 Сегеда С.П. Антропологічний склад... Табл. 6.2. С. 154.

30 Сегеда С.П. Древнейшие общности земледельцев и скотоводов Северного Причерноморья 5 тыс. до н. эры // Материалы международной конф. Кишинев, 10-14 декабря 1990 г. Киев, 1991. С. 98; Сегеда С.П. Позднеямное население Северо-Западного Причерноморья по антропологическим данным. Санкт-Петербург: ДОЗССП, 1991; Сегеда С.П. Антропологічний склад... Табл. 6.2. C. 155.

31 Алексеев В.П., Дебец Г.Ф. Краниометрия. Методика антропологических исследований. Москва: Наука, 1964. 128 с.; Martin R. Lehrbuch der Anthropologie in Systematischer Darstellung mit Besonderer Berücksichtigung der Anthropologischen Methoden für Studierende, Ärzte und Forschungsreisende. Bd. 2: Kraniologie, Osteologie. Second Edition. Iena: Gustav Fisher, 1928.

32 Зубов А.А. Одонтология. Методика антропологических исследований. Москва: Наука, 1968. 200 с.; Зубов А.А. Одонтоглифика: (Закономерности вариаций микрорельефа коронки моляров человека). Москва: Наука, 1973. 12 с. (Доклады Советской делегации / IX Междунар. конгресс антропол. и этногр. наук. (Чикаго, сент. 1973)).

33 Козинцев А.Г. Дискретные признаки на черепах эпохи бронзы из Южной Сибири. К проблемам методики изучения краниологического полиморфизма // Исследования по палеоантропологии и краниологии СССР. Москва, 1980. С. 75-99; Козинцев А.Г. Заднескуловая щель как расоразграничительный признак. // Вопросы антропологии. Вып. 74. 1984. С. 55-61; Козинцев А.Г. Использование дискретно-варьирующих краниологических признакою при индивидуальной диагностике. // Вопросы антропологии. 1973. Вып. 44. С. 136-141; Козинцев А.Г. Краниоскопия и расовая классификация // Советская этнография. 1987. Вып. 2. С. 12-31.

34 Kozintsev A. Ethnic Epigenetics: A New Approach // Homo. 1992. Vol. 43/3. P. 213-244.
}

Eminak, 2020, 3 (31) 
ли джерелом етногенетичної історії, яка формувалася на основі шовних варіацій для надзвичайно змішаних вибірок і стала однією з найважливіших складових реконструкції етногенезу, зокрема й носіїв культур епохи бронзи. До сьогодні ще не проводилося всебічне вивчення ямних і катакомбних серій з території України саме за краніоскопічними даними, що дало б змогу отримати нові джерела щодо етнічного й історичного розвитку населення епохи бронзи. У науковому обігу існує тільки одна невелика збірна серія з території України, яку дослідив А.В. Громов 35. Матеріали цього дослідження зберігаються у Санкт-Петербурзі.

У роботі для характеристики черепів з поховань катакомбної та ямної культур епохи ранньої та середньої бронзи з території сучасної України використовується краніоскопічна програма, яка включає п'ять ознак, які вперше дослідив О.Г. Козінцев: потиличний індекс, клиноподібний верхньощелепний шов, задньовиличний шов, підорбітний візерунок типу II, індекс поперечно-піднебінного шва ${ }^{36}$. Шосту ознаку - надорбітні отвори (НО) - незалежно один від одного запропонували Й. Додо ${ }^{37}$ і Т.В. Томашевич ${ }^{38}$. При вивченні потиличного індексу, задньовиличного шва, підорбітного візерунку типу II, індексу поперечно-піднебінного шва та надорбітних отворів дані складалися без урахування статі, для клиноподібного верхньощелепного шва визначалися півсуми даних чоловіків і жінок.

Деякі дискретно-варіативні ознаки на черепах (переважно за А.С.Беррі та Р. Дж. Беррі ${ }^{39}$ раніше відзначала С.І. Круц ${ }^{40}$, але тоді дослідження не було системним, позаяк описана методика О.Г. Козінцева не була до кінця розроблена.

Для порівняння груп за дискретно-варіативними ознаками використовувались комп’ютерні програми для реалізації багатомірного аналізу, які створили Б.О. та О.Г. Козінцеви 1991 р., а також метод головних компонент (ГК), одна з моделей факторного аналізу41.

Аналіз проводився за допомогою статистичної програми РССОМР, яка виконую повний аналіз ГК і вирішує зворотне факторне завдання: знаходить значення кожного компонента для кожного об'єкта. Програма PCDENDU виконує кластерний аналіз матриці евклідових дистанцій незваженим парно-груповим методом ${ }^{42}$. Дендрограми малювалися окремо з використанням програм Excel, Corel Draw-11 та 3D Max за результатами аналізу методу ГК, використовуючи координати центроїдів двох перших векторів. Попередньо, з метою стабілізації дисперсії, частоти перетворювалися на радіани за допомогою авторської програми, яку написав 1996 р. антрополог, к. і. н. А.В. Громов. Частоти ознак аналізованих груп та їх радіани подано у табл. 1.

\footnotetext{
35 Громов А.В. Антропология населения... Табл. 11. С. 155.

36 Козинцев А.Г. Дискретные признаки... С. 75-99; Козинцев А.Г. Заднескуловая щель... С. 55-61; Козинцев А.Г. Использование дискретно-варьирующих... С. 136-141; Козинцев А.Г. Краниоскопия и расовая... С. 12-31.

37 Dodo Y., Ishida H. Incidences of Nonmetric Cranial Variants in Several Population Samples From East Asia and North America // IASN. 1987. Vol. 95. N 2. P. 161-177.

38 Томашевич Т.В. Закономерности распределения частот подглазничных каналов черепа человека // Вопросы антропологии. Москва, 1988. Вып. 80. С. 119-128.

${ }^{39}$ Berry A.C., Berry R.I. Epigenetic Variation in the Human Cranium // Journal of Anatomy. 1967. Vol. 101. P. 361-379.

40 Круц С.И. Палеоантропологические исследования... С. 5.

41 Дерябин В.Е. Курс лекций по многомерной биометрии для антропологов. Москва: МГУ, биологический факультет, 2008. С. 76-117.

42 Дерябин В.Е. Курс лекций по многомерной биометрии... С. 230-276.
} 
Таблиця 1.

Частоти краніоскопічних ознак у краніологічній серії ямної та катакомбної культур з території України та порівняльні дані, \%.

\begin{tabular}{|c|c|c|c|c|c|c|c|c|}
\hline $\begin{array}{c}\text { № } \\
\text { П/П }\end{array}$ & Серія & Період & $\Pi I$ & ПОВ II & $3 B Ш$ & КВШ & ІППШ & $\mathrm{HO}$ \\
\hline 1. & $\begin{array}{l}\text { Ямна культура } 3 \\
\text { території Украї- } \\
\text { ни }\end{array}$ & $\begin{array}{l}\text { Епоха ран- } \\
\text { ньої та се- } \\
\text { редньої } \\
\text { бронзи }\end{array}$ & $\begin{array}{l}16,6 \\
(93)\end{array}$ & $\begin{array}{l}37,3 \\
(67)\end{array}$ & $\begin{array}{l}4,1 \\
(144)\end{array}$ & $\begin{array}{l}71,0 \\
(136)\end{array}$ & $\begin{array}{l}63,7 \\
(58)\end{array}$ & $\begin{array}{l}45,1 \\
(266)\end{array}$ \\
\hline 2. & $\begin{array}{l}\text { Катакомбна } \\
\text { культура з тери- } \\
\text { торії України }\end{array}$ & $\begin{array}{l}\text { Епоха ран- } \\
\text { ньої та се- } \\
\text { редньої } \\
\text { бронзи }\end{array}$ & $\begin{array}{l}26,0 \\
(70)\end{array}$ & $\begin{array}{l}21,2 \\
(33)\end{array}$ & $\begin{array}{l}2,3 \\
(87)\end{array}$ & $\begin{array}{l}61,8 \\
(97)\end{array}$ & $\begin{array}{l}68,0 \\
(50)\end{array}$ & $\begin{array}{l}41,3 \\
(116)\end{array}$ \\
\hline 3. & $\begin{array}{l}\text { Ямна та катако- } \\
\text { мбна культура } \\
\text { України (сумар- } \\
\text { но) }\end{array}$ & $\begin{array}{l}\text { Епоха ран- } \\
\text { ньої та се- } \\
\text { редньої } \\
\text { бронзи } \\
\text { (збірна се- } \\
\text { рія) } \\
\end{array}$ & $\begin{array}{l}21,2 \\
(163)\end{array}$ & $\begin{array}{l}32,0 \\
(100)\end{array}$ & $\begin{array}{l}3,4 \\
(231)\end{array}$ & $\begin{array}{l}67,0 \\
(233)\end{array}$ & $\begin{array}{l}65,7 \\
(108)\end{array}$ & $\begin{array}{l}43,9 \\
(382)\end{array}$ \\
\hline 4. & $\begin{array}{l}\text { Ямна та катако- } \\
\text { мбна культура } \\
\text { України (сумар- } \\
\text { но)**43 }\end{array}$ & - & $\begin{array}{l}23,6 \\
(36)\end{array}$ & $\begin{array}{l}46,1 \\
(13)\end{array}$ & $\begin{array}{l}3,8 \\
(26)\end{array}$ & $\begin{array}{l}26,3 \\
(44)\end{array}$ & - & $\begin{array}{l}53,2 \\
(62)\end{array}$ \\
\hline 5. & $\begin{array}{l}\text { Ямна культура } \\
\text { Калмикії та Аст- } \\
\text { раханської } \\
\text { обл.*44 }\end{array}$ & $\begin{array}{l}\text { Епоха ран- } \\
\text { ньої та се- } \\
\text { редньої } \\
\text { бронзи } \\
\end{array}$ & $\begin{array}{l}14,3 \\
(27)\end{array}$ & $\begin{array}{l}44,7 \\
(38)\end{array}$ & $\begin{array}{l}10,3 \\
(29)\end{array}$ & $\begin{array}{l}11,9 \\
(68)\end{array}$ & $\begin{array}{l}73,3 \\
(30)\end{array}$ & $\begin{array}{l}53,7 \\
(67)\end{array}$ \\
\hline 6. & $\begin{array}{l}\text { Катакомбна } \\
\text { культура Волго- } \\
\text { градської обл. } \\
\text { (не деформова- } \\
\text { ні)*45 }\end{array}$ & $\begin{array}{l}\text { Епоха ран- } \\
\text { ньої та се- } \\
\text { редньої } \\
\text { бронзи }\end{array}$ & $\begin{array}{l}11,1 \\
(26)\end{array}$ & $\begin{array}{l}42,1 \\
(19)\end{array}$ & $\begin{array}{l}8,7 \\
(23)\end{array}$ & $\begin{array}{l}23,0 \\
(31)\end{array}$ & $\begin{array}{l}87,5 \\
(8)\end{array}$ & $\begin{array}{l}37,2 \\
(43)\end{array}$ \\
\hline 7. & \begin{tabular}{lr}
\multicolumn{2}{l}{ Катакомбна } \\
культура Рос- \\
товської & обл. \\
Лівий & берег До- \\
ну (не & де- \\
форм.) $^{* 46}$ & \\
\end{tabular} & $\begin{array}{l}\text { Епоха ран- } \\
\text { ньої та се- } \\
\text { редньої } \\
\text { бронзи }\end{array}$ & $\begin{array}{l}10,0 \\
(41)\end{array}$ & $\begin{array}{l}46,2 \\
(52)\end{array}$ & $\begin{array}{l}19,5 \\
(41)\end{array}$ & $\begin{array}{l}16,3 \\
(90)\end{array}$ & $\begin{array}{l}78,0 \\
(59)\end{array}$ & $\begin{array}{l}46,7 \\
(107)\end{array}$ \\
\hline 8. & \begin{tabular}{lr}
\multicolumn{2}{l}{ Катакомбна } \\
культура Рос- \\
товської \\
Правий обл. \\
$\begin{array}{lr}\text { Дону (нерег } \\
\text { форм.)*47 }\end{array}$ \\
\end{tabular} & $\begin{array}{l}\text { Епоха ран- } \\
\text { ньої та се- } \\
\text { редньої } \\
\text { бронзи }\end{array}$ & $\begin{array}{l}11,1 \\
(34)\end{array}$ & $\begin{array}{l}61,7 \\
(47)\end{array}$ & $\begin{array}{l}12,8 \\
(39)\end{array}$ & $\begin{array}{l}8,3 \\
(68)\end{array}$ & $\begin{array}{l}76,3 \\
(38)\end{array}$ & $\begin{array}{l}44,6 \\
(139)\end{array}$ \\
\hline
\end{tabular}

\footnotetext{
43 Казарницкий А.А. Краниоскопия населения... С. 76-83.

44 Ibidem.

45 Ibidem.

46 Ibidem.

47 Ibidem.
} 


\begin{tabular}{|c|c|c|c|c|c|c|c|c|}
\hline 9. & \begin{tabular}{l}
\multicolumn{3}{l}{ Катакомбна } \\
культура Кал- \\
микії (не де- \\
форм.) *
\end{tabular} & $\begin{array}{l}\text { Епоха ран- } \\
\text { ньої та се- } \\
\text { редньої } \\
\text { бронзи }\end{array}$ & $\begin{array}{l}13,3 \\
(47)\end{array}$ & $\begin{array}{l}43,9 \\
(41)\end{array}$ & $\begin{array}{l}7,0 \\
(43)\end{array}$ & $\begin{array}{l}24,3 \\
(40)\end{array}$ & $\begin{array}{l}71,4 \\
(42)\end{array}$ & $\begin{array}{l}52,2 \\
(67)\end{array}$ \\
\hline 10. & $\begin{array}{l}\text { Окунівська куль- } \\
\text { тура сумарно (3 } \\
\text { Черновою, Вер- } \\
\text { хнього Аскізу, } 3 \\
\text { поховань уйбат- } \\
\text { ського типу) *48 }\end{array}$ & $\begin{array}{l}\text { Окунівська } \\
\text { культура }\end{array}$ & $\begin{array}{l}20,0 \\
(131)\end{array}$ & $\begin{array}{l}29,0 \\
(179)\end{array}$ & $\begin{array}{l}7,9 \\
(201)\end{array}$ & $\begin{array}{l}29,3 \\
(387)\end{array}$ & $\begin{array}{l}58,4 \\
(166)\end{array}$ & $\begin{array}{l}53,3 \\
(285)\end{array}$ \\
\hline
\end{tabular}

Умовні позначення: Тут та далі: ПІ - потиличний індекс, КВШ - клиноподібнийверхньощелепний шов, ЗВШ - задньовиличний шов, ПОВ-II - підорбітний візерунок типу II, ІППШ - індекс поперечного піднебінного шва, НО - надорбітні отвори. В дужках указано загальна кількість спостережень.

* Величини, які вирахували А.В. Громов та А.А. Казарницький.

** Величини, які вирахував А.В. Громов (матеріали зберігаються в Санкт-Петербурзі).

Матеріал ранньої та середньої бронзи, опрацьований у цій роботі, відібрали Ю.В.Ушкова 49 й автор статті з території Надпоріжжя, Південної (Запорізька, Херсонська, Миколаївська обл.), а також Східної (Донецька обл.) України. До серії катакомбної культури входить 72 поховання (Табл. 2). До серії ямної культури входить 181 поховання (Табл. 3). У цілому досліджено 253 черепа. Матеріал зберігається у Фондах Інституту археології НАНУ.

Таблиця 2.

Серія носіїв катакомбної культури

\begin{tabular}{|c|c|c|c|c|c|c|}
\hline \begin{tabular}{|c|} 
№ \\
П/ா
\end{tabular} & $\begin{array}{c}\text { Населений } \\
\text { пункт, колгосп }\end{array}$ & Курган & $\begin{array}{l}\text { Похо- } \\
\text { вання }\end{array}$ & $\begin{array}{l}\text { Кістяк / } \\
\text { череп }\end{array}$ & $\begin{array}{c}\text { Інвен- } \\
\text { тарний } \\
\text { №* }\end{array}$ & $\begin{array}{l}\text { Назва експе- } \\
\text { диції, рік, лі- } \\
\text { тература }\end{array}$ \\
\hline 1. & Базавлук & 1 & 5 & - & - & \multirow{3}{*}{$\begin{array}{l}\text { Черних, Дара- } \\
\text { ган, Долженко, } \\
2015,2018^{50}\end{array}$} \\
\hline 2. & Базавлук & 1 & 3 & - & - & \\
\hline 3. & Базавлук & 1 & 2 & - & - & \\
\hline 4. & Орджонікідзе & 31 & 8 & 1 & - & \multirow[t]{5}{*}{ OAE-200351. } \\
\hline 5. & Орджонікідзе & 29 & 8 & - & - & \\
\hline 6. & Орджонікідзе & - & 13 & - & - & \\
\hline 7. & Орджонікідзе & 29 & 9 & - & - & \\
\hline 8. & Орджонікідзе & 18 & 17 & 1 & - & \\
\hline
\end{tabular}

48 Козинцев А.Г. Указ. раб.

49 Щиро дякую Ю.В. Ушковій за допомогу в створенні двох серій епохи бронзи з території України та консультації.

50 Долженко Ю.В. Краниометрическая характеристика мужских черепов из катакомбных погребений, исследованных Орджоникидзевской археологической экспедицией. Додаток II 3 // Черных Л.А., Дараган М.Н. Курганы эпохи энеолита - бронзы междуречья Базавлук - Соленая - Чертомлык. Киев: Олег Філюк. 2015. С. 521-527; Черных Л.А., Дараган М.Н. Курганы эпохи энеолита бронзы междуречья Базавлук - Соленая - Чертомлык. Киев: Олег Філюк. 2015; Долженко Ю.В. Краниологическая изменчивость носителей катакомбной культуры из степного Приднепровья // Scriptorium nostrum. Вип. 1 (10). 2018. С. 39-73.

51 Долженко Ю.В. Краниометрическая характеристика мужских... С. 521-527; Полин С., Черных Л., Дараган М., Разумов С. Исследования курганов эпохи бронзы и скифского периода у г. Орджоникидзе (Украина) в 2007 г. // Revista Arheologica. S.N. 2008. Вып. IV. № 1. C. 135-145. 


\begin{tabular}{|c|c|c|c|c|c|c|}
\hline 9. & $\begin{array}{l}\text { Волошино, Пол- } \\
\text { тавська обл. }\end{array}$ & $\begin{array}{c}\text { 1, кур- } \\
\text { ганна } \\
\text { група } 1 \\
\end{array}$ & 42 & - & - & 200452 \\
\hline 10. & Дуканичі & $\begin{array}{c}\text { 1, кур- } \\
\text { ганна } \\
\text { група 1 } \\
\end{array}$ & $\begin{array}{c}\text { 1, впуск- } \\
\text { не }\end{array}$ & - & - & $2005^{53}$ \\
\hline 11. & - & 3 & 1 & 1 & - & КГОБ-1985 \\
\hline 12. & $\begin{array}{l}\text { с. Шахтар (Шев- } \\
\text { ченкове), Кривий } \\
\text { Ріг }\end{array}$ & 3 & 4 & - & $3367^{*}$ & Круц, 198454 \\
\hline 13. & $\begin{array}{l}\text { Кривий Ріг, к. } \\
\text { Лук'янівка, }\end{array}$ & $\begin{array}{c}\text { курган } \\
\text { Лук'я- } \\
\text { нівка } \\
\end{array}$ & 25 & - & - & КІКМ-1981 \\
\hline 14. & $\begin{array}{l}\text { с. Широкий Інгу- } \\
\text { лець, }\end{array}$ & 3 & 16 & - & 3350 & $\begin{array}{l}\text { Зиневич, } \\
196755\end{array}$ \\
\hline 15. & к. Лук’янівка & - & 9 & - & - & \multirow[t]{2}{*}{ KAE-1981 } \\
\hline 16. & к. Лук'янівка & - & 14 & - & - & \\
\hline 17. & $\begin{array}{l}\text { Кам'янка- } \\
\text { Дніпровська }\end{array}$ & 11 & 17 & - & 12123 & \multirow[t]{3}{*}{ ЗПЕ-1986 } \\
\hline 18. & $\begin{array}{l}\text { Кам'янка- } \\
\text { Дніпровська }\end{array}$ & - & 5 & 1 & - & \\
\hline 19. & $\begin{array}{l}\text { Кам'янка- } \\
\text { Дніпровська }\end{array}$ & 11 & 10 & - & 12110 & \\
\hline 20. & В. Тарасівка & 70 & 4 & - & - & BTE-1975 \\
\hline 21. & В. Тарасівка & 59 & 20 & 3 & - & BTE-197556 \\
\hline 22. & с. Цілинне & 6 & 10 & череп 3 & 8565 & CKE-78 \\
\hline 23. & с. Звенигород-ка & 1 & 4 & - & - & \multirow[t]{7}{*}{ KE-1991 } \\
\hline 24. & с. Звенигородка & 1 & 5 & - & - & \\
\hline 25. & с. Звенигородка & 4 & 6 & - & - & \\
\hline 26. & с. Звенигородка & 3 & - & - & - & \\
\hline 27. & с. Звенигородка & 2 & - & - & - & \\
\hline 28. & с. Звенигородка & 5 & - & - & - & \\
\hline 29. & с. Звенігородка & 7 & - & - & - & \\
\hline 30. & Запоріжжя & - & 4 & - & 1192 & CP-196957 \\
\hline 31. & Виноградне & 24 & 15 & 1 & - & \multirow[t]{8}{*}{ ЗПЕ-1984 } \\
\hline 32. & Виноградне & 24 & 15 & 2 & - & \\
\hline 33. & Виноградне & 24 & 19 & 1 & - & \\
\hline 34. & Виноградне & 3 & 36 & 2 & - & \\
\hline 35. & Виноградне & 24 & 32 & - & - & \\
\hline 36. & Виноградне & 24 & 17 & 1 & 1903-1 & \\
\hline 37. & Виноградне & 24 & 26 & - & - & \\
\hline 38. & Виноградне & 24 & 22 & - & - & \\
\hline
\end{tabular}

52 Супруненко О.Б., Шерстюк В.В. Кургани Нижнього Припсілля. Київ, 2011. 472 с.

53 Супруненко О.Б. Кургани між сс. Дуканичі та Солонці на нижньому Пслі. Київ-Полтава: Центр пам'яток НАНУ і УТОПІК, ЦОДПА, 2006. 138 с. (Старожитності околиць Комсомольська. Ч. IV).

${ }_{54}$ Круц С.И. Палеоантропологические исследования...

55 Зиневич Г.П. Очерки палеоантропологии...

56 Круц С.И. К антропологии древнего населения Запорожской области // Палеоантропологические материалы из могильников Украины. Киев: Наукова думка, 1979. С. 3-22.

57 Ibidem. 


\begin{tabular}{|c|c|c|c|c|c|c|}
\hline 39. & Виноградне & 8 & 1 & 2 & - & \\
\hline 40. & Виноградне & 12 & 1 & - & - & \\
\hline 41. & Виноградне & 2 & 8 & - & 7514 & \\
\hline 42. & Виноградне & 2 & 20 & - & - & \\
\hline 43. & Голубівка & 3 & 16 & 4 & - & 2006 \\
\hline 44. & Сугоклея & - & 13 & - & - & 2004 \\
\hline 45. & Ш. «Степова» & 2 & 4 & - & - & \multirow{2}{*}{ Круц, 197958} \\
\hline 46. & Ш. «Степова» & 4 & 10 & - & - & \\
\hline 47. & $\begin{array}{l}\text { г. Пологи, } \\
\text { к. Соколовський }\end{array}$ & - & 11 & - & - & ЗКМ 1977 \\
\hline 48. & Царівка & 4 & 2 & - & - & Д-1980 \\
\hline 49. & Головківка & 10 & 7 & - & - & KE-1990 \\
\hline 50. & $\begin{array}{l}\text { Полтавська обл., } \\
\text { Волошино }\end{array}$ & 1 & 27 & - & - & 200459 \\
\hline 51. & Радіонівка & 2 & 3 & кістяк 1 & 1007 & XAE-1982 \\
\hline 52. & Христофорівка & 1 & 6 & - & - & IE-1973 \\
\hline 53. & с. Цілинне & 6 & 8 & 2 & 6502 & СКЕ-1978 \\
\hline 54. & с. Сергіївка & 1 & 12 & - & 584 & XAE-1976 \\
\hline 55. & Н. Бараніківка & 5 & 8 & - & 1505 & ДАЕ-1977 \\
\hline 56. & Довгий курган & & 17 & - & & $\begin{array}{l}\text { CPE-(ЗПЕ)- } \\
1969\end{array}$ \\
\hline 57. & Б. Белоз & 2 & 9 & - & 7803 & ЗПЕ-1975 \\
\hline 58. & с. Заможне & 8 & 1 & - & & \multirow[t]{2}{*}{ ЗПЕ-1981 } \\
\hline 59. & с. Заможне & 5 & 7 & - & 6603 & \\
\hline 60. & $\begin{array}{l}\text { Балківський кур- } \\
\text { ган }\end{array}$ & - & 36 & - & - & ЗПЕ-1973 \\
\hline 61. & Барвинівка & 5 & 9 & - & - & 1986 \\
\hline 62. & с. Видножина & 5 & 6 & - & - & ЗПЕ-1987 \\
\hline 63. & Златополь & 7 & 32 & - & - & ЗПЕ-1973 \\
\hline 64. & Родіонівка & 2 & 8 & - & - & XAE-1982 \\
\hline 65. & Цегляний завод & 4 & 2 & - & - & - \\
\hline 66. & - & 2 & 8 & - & - & СКE-1965 (3?) \\
\hline 67. & Успенка & 1 & 12 & - & - & KE-1989 \\
\hline 68. & Тамарино & 1 & 15 & 2 & - & HE-1987 \\
\hline 69. & Отрадне & 25 & 11 & - & - & IE-1971 \\
\hline 70. & с. Софіївка & 5 & 3 & - & - & XAE-1972 \\
\hline 71. & Томарино & 1 & 14 & 3 & 9773 & HE-1987 \\
\hline 72. & $\begin{array}{l}\text { курганна група } \\
\text { Рибасово-2, } \\
\text { м. Кривий Ріг }\end{array}$ & 3 & 4 & - & - & КІКМ-1986 \\
\hline
\end{tabular}

Круц С.И., Шепель Е.А., Сегеда С.П., Потехина И.Д., Покас П.М., Назарова Т.А., Литвинова Л.В., Рудич Т.А. Каталог палеоантропологических коллекций ИА АН УССР: В 2 т. Киев: НА IA НАНУ, ПТ № 118, 1986. T. 1.300 c. 
Таблиця 3.

Серія носіїв ямної культури

\begin{tabular}{|c|c|c|c|c|c|c|}
\hline $\begin{array}{l}\text { № } \\
\text { П/ } \\
\text { П }\end{array}$ & $\begin{array}{c}\text { Населений } \\
\text { пункт, колгосп }\end{array}$ & Курган & $\begin{array}{c}\text { Похован- } \\
\text { ня }\end{array}$ & $\begin{array}{c}\text { Кістяк / } \\
\text { череп }\end{array}$ & $\begin{array}{c}\text { Iнвентар- } \\
\text { ний№* }\end{array}$ & $\begin{array}{c}\text { Назва } \\
\text { експеди- } \\
\text { ції, рік, } \\
\text { літерату- } \\
\text { ра }\end{array}$ \\
\hline 1. & $\begin{array}{l}\text { Полтавська обл., } \\
\text { Волошино, кур- } \\
\text { ганна група } 1\end{array}$ & 2 & 46 & - & - & 2005 \\
\hline 2. & с. Нагірне & 48 & 2 & скелет 2 & - & CAE-1980 \\
\hline 3. & Кривий Ріг & $\begin{array}{l}\text { к. } \\
\text { Лук'янівка }\end{array}$ & 23 & череп-2, & - & 1981 \\
\hline 4. & Широке & 3 & 7 & - & $3366^{*}$ & $\begin{array}{l}\text { Інгулець- } \\
\text { ка-1965, }\end{array}$ \\
\hline 5. & Кривий Ріг & 1 & 10 & - & $\begin{array}{l}\text { № 3360, № } \\
464\end{array}$ & $\begin{array}{l}\text { ЮГОК- } \\
1964 \\
\end{array}$ \\
\hline 6. & Баштечки & 16 & 3 & - & 6954 & CAE-1979 \\
\hline 7. & Баштечки & 15 & 1 & - & - & CAE-1979 \\
\hline 8. & Баштечки & 6 & 3 & - & 6986 & CAE-1979 \\
\hline 9. & Баштечки & 19 & 3 & - & 6990 & CAE-1979 \\
\hline 10. & Баштечки & 54 & 1 & - & 6998 & CAE-1979 \\
\hline 11. & Баштечки & 54 & 3 & - & 6994 & CAE-1979 \\
\hline 12. & Баштечки & 5 & 1 & - & 6985 & CAE-1979 \\
\hline 13. & Баштечки & 55 & 1 & - & 6977 & CAE-1979 \\
\hline 14. & Баштечки & 19 & 4 & - & 6957 & CAE-1979 \\
\hline 15. & Баштечки & $28 ?$ & 1 & - & 7981 & CAE-1979 \\
\hline 16. & Баштечки & 20 & 1 & - & 6958 & CAE-1979 \\
\hline 17. & Баштечки & 20 & 2 & - & 6959 & CAE-1979 \\
\hline 18. & Баштечки & 42 & - & - & - & CAE-1979 \\
\hline 19. & Баштечки & 4 & 2 & - & 6946 & CAE-1979 \\
\hline 20. & Баштечки & $23 a$ & 1 & - & 6962 & CAE-1979 \\
\hline 21. & Баштечки & 58 & 2 & - & 6979 & CAE-1979 \\
\hline 22. & Баштечки & 40 & 2 & - & 6963 & CAE-1979 \\
\hline 23. & Баштечки & 58 & 1 & - & - & CAE-1979 \\
\hline 24. & Баштечки & 58 & 3 & - & 6980 & CAE-1979 \\
\hline 25. & с. Сергіївка & 1 & 16 & & 4285 & XAE-1976 \\
\hline 26. & с. Сергіївка & 1 & 17 & кістяк 1 & - & XAE-1976 \\
\hline 27. & с. Сергіївка & 1 & 17 & кістяк 2 & - & XAE-1976 \\
\hline 28. & Холмське & 2 & 13 & - & - & I3AE-1978 \\
\hline 29. & с. Багате & 2 & 11 & - & - & I3AE-1978 \\
\hline 30. & с. Багате & 2 & 12 & - & 4844 & I3AE-1978 \\
\hline 31. & с. Багате & 3 & 1 & - & - & I3AE-1978 \\
\hline 32. & с. Багате & 2 & 8 & - & 4998 & I3AE-1978 \\
\hline 33. & Александровськ & 7 & 5 & - & 1616 & 1972 \\
\hline 34. & Александровськ & 4 & 3 & кістяк 1 & - & 1972 \\
\hline 35. & - & 12 & 5 & - & 4583 & IзAE-1980 \\
\hline 36. & Чауш, Плавні & 20 & 2 & - & - & IзAE-1981 \\
\hline 37. & Нагірне & 15 & 10 & - & 4680 & IзAE-1982 \\
\hline
\end{tabular}




\begin{tabular}{|c|c|c|c|c|c|c|}
\hline 38. & Нагірне & 15 & 1 & - & 4676 & I3AE-1982 \\
\hline 39. & Плавні & 1 & 3 & - & - & IзAE-1979 \\
\hline 40. & Плавні & 8 & 29 & - & - & ІзAE-1979 \\
\hline 41. & Плавні & 8 & 18 & - & 4951 & ІзАE-1979 \\
\hline 42. & Каланчак & 3 & 22 & - & - & I3AE-1982 \\
\hline 43. & Нагірне & 15 & 13 & - & 4681 & I3AE-1982 \\
\hline 44. & - & 1 & 5 & - & 4990 & ІзAE-1984 \\
\hline 45. & Фрікацей & 10 & 14 & - & 4813 & ІзAE-1981 \\
\hline 46. & Баранівка & 2 & 7 & - & 1652 & ВСД-1976 \\
\hline 47. & Сватове & 2 & 1 & - & 3590 & СД-1973 \\
\hline 48. & Провальє (Майка) & 4 & 11 & - & 1812 & СД-1978 \\
\hline 49. & Провальє (Майка) & 4 & 4 & - & 1769 & СД-1978 \\
\hline 50. & Новоселівка & 1 & 16 & - & 1611 & СД-1975 \\
\hline 51. & Говоруха & 10 & 2 & - & 1955 & СД-1976 \\
\hline 52. & Александровськ & 1 & 46 & - & 1579 & СД-1972 \\
\hline 53. & с. Н. Григорівка & 1 & 13 & - & 8648 & СД-1974 \\
\hline 54. & Майорівка & 4 & 15 & - & 8940 & 1971 \\
\hline 55. & Майорівка & 5 & 3 & - & 8943 & 1971 \\
\hline 56. & Булгаково & 1 & 16 & - & 931 & IE-1974 \\
\hline 57. & ст. Гороженко & 2 & 10 & - & 1376 & IE-1969 \\
\hline 58. & с. Н. Григорівка & 1 & 14 & - & 8576 & IE-1974 \\
\hline 59. & Антонівка & 8 & 17 & - & & IE-1975 \\
\hline 60. & Соколівка & 1 & 13 & - & $\begin{array}{l}\text { № } 10621 \\
\text { та } 1363 \\
\end{array}$ & IE-1969 \\
\hline 61. & Привольне & 2 & 4 & - & 8947 & IE-1970 \\
\hline 62. & Соколівка & 3 & 16 & - & 8036 & IE-1969 \\
\hline 63. & Новопетрівка & 4 & 4 & - & 8790 & IE-1975 \\
\hline 64. & п. Бугський & 2 & 7 & скелет 1 & 6709 & IE-1977 \\
\hline 65. & п. Бугський & 2 & 16 & - & 8646 & IE-1977 \\
\hline 66. & Мефодієвка & 4 & 8 & - & - & IE-1977 \\
\hline 67. & п. Бугський & 1 & 12 & - & 8645 & IE-1977 \\
\hline 68. & Майорівка & 3 & 9 & - & - & IE-1971 \\
\hline 69. & Майорівка & 3 & 7 & - & 8966 & IE-1971 \\
\hline 70. & п. Бугський & 2 & 7 & скелет 5 & - & IE-1977 \\
\hline 71. & с. Отрадне & 9 & 10 & - & 8598 & IE-1970 \\
\hline 72. & с. Привольне & 1 & 6 & - & 8593 & IE-1970 \\
\hline 73. & Яківка & 1 & 4 & - & 9764 & $\begin{array}{l}\text { IE - } \\
1986 / 18\end{array}$ \\
\hline 74. & $\begin{array}{l}\text { Миколаївська } \\
\text { обл., } \\
\text { с. Новопетрівка, } \\
\text { Братський р-н }\end{array}$ & 4 & 5 & - & - & IE-1975 \\
\hline 75. & Таборівка & 1 & 20 & - & 8748 & IE-1977 \\
\hline 76. & Висунськ & 1 & 22 & - & 8614 & IE-1977 \\
\hline 77. & Таборівка & 1 & 16 & - & 6706 & IE-1977 \\
\hline 78. & Комінтерн & 26 & 5 & - & 516 & IE-1975 \\
\hline 79. & Касперівка & 3 & - & - & 3469 & IE-1974 \\
\hline 80. & Бугський & 1 & 15 & Кістяк 1 & - & IE-1977 \\
\hline 81. & Таборівка & 1 & 7 & - & 8633 & IE-1977 \\
\hline 82. & Таборівка & 1 & 6 & - & 6702 & IE-1977 \\
\hline
\end{tabular}




\begin{tabular}{|c|c|c|c|c|c|c|}
\hline 83. & Іванівка & 1 & 5 & - & 8616 & IE-1977 \\
\hline 84. & Н. Одеса - II & 10 & 8 & - & 8001 & IE-1974 \\
\hline 85. & Вісунськ & 1 & 23 & - & 8617 & IE-1974 \\
\hline 86. & Старогорожине & & & - & 8911 & IE-1969 \\
\hline 87. & Таборівка & 1 & 19 & скелет 2 & 8631 & IE-1977 \\
\hline 88. & Петропавлівський & 2 & 3 & - & - & - \\
\hline 89. & $\begin{array}{l}\text { Михайлівка, } \\
\text { Херсонська обл. }\end{array}$ & 10 & 7 & могила 1 & 817 & 1957 \\
\hline 90. & Баштанівка & 7 & 16 & - & - & ДДЕ-1966 \\
\hline 91. & с. Глибоке & 1 & 11 & - & - & ДДЕ-1965 \\
\hline 92. & с. Глибоке & 1 & 7 & - & - & ДДЕ-1965 \\
\hline 93. & с. Глибоке & 1 & 24 & - & - & ДДЕ-1965 \\
\hline 94. & с. Глибоке & 1 & 25 & - & 5225 & ДДЕ-1965 \\
\hline 95. & с. Глибоке & 2 & 7 & - & 5317 & ДДЕ-1965 \\
\hline 96. & Борисівка & 9 & 11 & - & - & ДДЕ-1965 \\
\hline 97. & Кальчево & 3 & 14 & - & - & ДДЕ-1986 \\
\hline 98. & Миколаївка & 4 & 9 & - & 5290 & ДДЕ-1969 \\
\hline 99. & Градешти & $6 / 1$ & 1 & - & 7877 & ДДЕ-1983 \\
\hline 100. & Білолісся & 3 & 24 & - & 4826 & ДДЕ-1980 \\
\hline 101. & - & 52 & 40 & - & 4828 & ДДЕ-1979 \\
\hline 102. & Миколаївка & 4 & 8 & - & 3339 & ДДЕ-1969 \\
\hline 103. & с. В. Тарасівка & 1 & 6 & - & - & BTE-1973 \\
\hline 104. & Павлівка & 27 & 15 & - & 6131 & HE-1984 \\
\hline 105. & Таборівка & 26 & 13 & - & - & HE-1983 \\
\hline 106. & Таборівка & 25 & 6 & - & - & HE-1983 \\
\hline 107. & Павлівка & 27 & 10 & - & - & HE-1984 \\
\hline 108. & Ахтово & 7 & 12 & - & 9793 & HE-1987 \\
\hline 109. & Мар'янівка & 7 & 5 & - & - & $\begin{array}{l}\text { HE- } \\
1986 / 18\end{array}$ \\
\hline 110. & Виноград. Сад. & 4 & 4 & - & - & HE-1984/9 \\
\hline 111. & Павлівка & 24 & 7 & - & 6150 & HE-1984/9 \\
\hline 112. & Пришиб & 14 & 18 & - & - & HE-1984/9 \\
\hline 113. & Н. Оселівка & 19 & 7 & - & - & КЗЕ-1974 \\
\hline 114. & Підлисівка & 1 & 16 & - & - & ЯЕ-2010 \\
\hline 115. & Александровськ & 4 & 2 & кістяк 2 & - & 1972 \\
\hline 116. & с. Нерушай & 9 & 84 & - & 5367 & - \\
\hline 117. & Сугоклія & $\begin{array}{l}\text { Сугоклій- } \\
\text { ський кур- } \\
\text { ган }\end{array}$ & 26 & - & - & 2004 \\
\hline 118. & Сугоклея & $\begin{array}{l}\text { Сугоклій- } \\
\text { ський кур- } \\
\text { ган }\end{array}$ & 16 & - & - & 2004 \\
\hline 119. & Сугоклія & $\begin{array}{l}\text { Сугоклій- } \\
\text { ський кур- } \\
\text { ган }\end{array}$ & 24 & - & - & 2004 \\
\hline 120. & Сугоклія & $\begin{array}{l}\text { Сугоклій- } \\
\text { ський кур- } \\
\text { ган }\end{array}$ & 20 & - & - & 2004 \\
\hline 121. & Сугоклія & $\begin{array}{l}\text { Сугоклій- } \\
\text { ський кур- }\end{array}$ & 8 & - & - & 2004 \\
\hline
\end{tabular}




\begin{tabular}{|c|c|c|c|c|c|c|}
\hline & & ган & & & & \\
\hline 122. & Сугоклія & $\begin{array}{l}\text { Сугоклій- } \\
\text { ський кур- } \\
\text { ган }\end{array}$ & 10 & - & - & 2004 \\
\hline 123. & с. Виноградне & 19 & 9 & скелет 2 & - & ЗПЕ-1984 \\
\hline 124. & с. Виноградне & 18 & 9 & скелет 1 & - & ЗПЕ-1984 \\
\hline 125. & с. Виноградне & 19 & 9 & кістяк 3 & - & ЗПЕ-1984 \\
\hline 126. & с. Виноградне & 18 & 9 & скелет 2 & - & ЗПЕ-1984 \\
\hline 127. & с. Виноградне & 29 & 2 & - & - & ЗПЕ-1984 \\
\hline 128. & с. Виноградне & - & $?$ & - & - & ЗПЕ-1984 \\
\hline 129. & с. Виноградне & 26 & 6 & - & 1907 & ЗПЕ-1984 \\
\hline 130. & с. Виноградне & 4 & - & 13 & 7518 & ЗПЕ-1984 \\
\hline 131. & с. Виноградне & 3 & 10 & - & 7522 & ЗПЕ-1982 \\
\hline 132. & с. Виноградне & 24 & 31 & - & & ЗПЕ-1984 \\
\hline 133. & с. Виноградне & 3 & 25 & - & 7523 & ЗПЕ-1982 \\
\hline 134. & с. Виноградне & 24 & 24 & - & - & ЗПЕ-1984 \\
\hline 135. & $\begin{array}{l}\text { Новочерноморья, } \\
\text { Херсонська обл. }\end{array}$ & 9 & 4 & - & 3305 & ЮУЕ-1963 \\
\hline 136. & $\begin{array}{l}\text { Новочерноморья, } \\
\text { Херсонська обл. }\end{array}$ & 2 & 11 & - & 840 & ЮУЕ-1963 \\
\hline 137. & с. Покровка & 3 & 6 & - & 7044 & ЮБЕ-1976 \\
\hline 138. & с. Покровка & 3 & 12 & - & 4319 & ЮБЕ-1976 \\
\hline 139. & $\begin{array}{l}\text { Новочорномор'я } \\
\text { Херсонська обл. }\end{array}$ & 8 & 9 & - & - & ЮУЕ-1963 \\
\hline 140. & Ковалівка & $\begin{array}{l}\text { курганна } \\
\text { група IV, к. } \\
1\end{array}$ & 12 & - & - & ЮБЕ-1971 \\
\hline 141. & Покровка & 2 & 3 & - & - & ЮБЕ-1976 \\
\hline 142. & Покровка & 4 & 2 & - & - & ЮБЕ-1976 \\
\hline 143. & Ковалівка-VI & 4 & 17 & - & - & ЮБЕ-1976 \\
\hline 144. & Ковалівка-VI & 2 & 2 & - & - & ЮБЕ-1976 \\
\hline 145. & Ковалівка & $\begin{array}{l}\text { Курганна } \\
\text { група VII, } \\
\text { к. } 3\end{array}$ & 11 & - & - & ЮБЕ-1974 \\
\hline 146. & с. Целінне & 7 & 1,6 & - & 8464 & KE-1978 \\
\hline 147. & с. Істочне & 12 & 5 & - & - & CKE-1978 \\
\hline 148. & В. Тарасівка & 9 & 18 & - & - & BTE-1975 \\
\hline 149. & Софіївка & 1 & 9 & - & - & 1967 \\
\hline 150. & Ізм., с. Фрікауей & 10 & 10 & - & 4823 & AE-1981/1 \\
\hline 151. & $\begin{array}{l}\text { с. Комінтерн Ми- } \\
\text { колаївської обл., } \\
\text { Снігиревський р- } \\
\text { н }\end{array}$ & - & - & - & № 517 & 1975 \\
\hline 152. & Ш. Степова & 2 & 5 & - & - & 2008 \\
\hline 153. & $\begin{array}{l}\text { Миколаївська } \\
\text { обл., с. Нечаянне }\end{array}$ & 2 & 7 & - & 514 & 1976 \\
\hline 154. & Голубівка & 3 & 10 & кістяк 4 & - & 2006 \\
\hline 155. & Песчанка & $\begin{array}{l}\text { кург. Гру- } \\
\text { па 2, кур- } \\
\text { ган } 1\end{array}$ & 10 & - & - & 2007 \\
\hline
\end{tabular}




\begin{tabular}{|c|c|c|c|c|c|c|}
\hline 156. & Песчанка & $\begin{array}{l}\text { курганна } \\
\text { група 2, } \\
\text { курган } 1\end{array}$ & 15 & - & - & 2007 \\
\hline 157. & Старосілля & 3 & 23 & - & 1585 & XAE-1972 \\
\hline 158. & Старосілля & 3 & 8 & - & 10775 & XAE-1972 \\
\hline 159. & с. Львове & 7 & 14 & - & - & XAE-1973 \\
\hline 160. & Софіївка & 23 & 15 & - & - & XAE-1973 \\
\hline 161. & Софіївка & 4 & 2 & - & 1522 & XAE-1972 \\
\hline 162. & Любимівка & 19 & 5 & - & - & XAE-1986 \\
\hline 163. & Любимівка & 13 & 7 & - & 10681 & XAE-1986 \\
\hline 164. & Любимівка & $13(1)$ & 6 & - & 10680 & XAE-1986 \\
\hline 165. & с. Богданівка & 2 & 11 & - & - & XAE-1974 \\
\hline 166. & Вишневий сад & $\begin{array}{l}\text { курганна } \\
\text { група II, к. } \\
1\end{array}$ & 8 & - & 9725 & $\begin{array}{l}\text { Миколаїв- } \\
\text { ська екс- } \\
\text { педиція }\end{array}$ \\
\hline 167. & $\begin{array}{l}\text { Херсонська обл. с. } \\
\text { Красне }\end{array}$ & - & 2 & - & 424 & 1963 \\
\hline 168. & $\begin{array}{l}\text { НАЕ - ДОКМ Ми- } \\
\text { колаївка }\end{array}$ & 1 & 12 & - & - & 1989 \\
\hline 169. & - & 13 & 1 & - & 6491 & $\begin{array}{l}\text { Північно } \\
\text { Кримська } \\
\text { експеди- } \\
\text { ція }\end{array}$ \\
\hline 170. & $\begin{array}{l}\text { Херсонська обл., } \\
\text { Чапл. Отр, Група } 6 \\
\text { км. }\end{array}$ & 1 & 7 & - & 10549 & 1962 \\
\hline 171. & $\begin{array}{l}\text { Херсонська обл., } \\
\text { колгосп «Радян- } \\
\text { ська Україна» }\end{array}$ & 4 & 5 & - & 3319 & 1963 \\
\hline
\end{tabular}

* Круц С.И., Шепель Е.А., Сегеда С.П., Потехина И.Д., Покас П.М., Назарова Т.А., Литвинова Л.В., Рудич Т.А. Каталог палеоантропологических коллекций ИА АН УССР: В 2 т. Киев: НА ІА НАНУ. ПТ № 118.1986. T. 1.300 c.

Зупинимося на кожній ознаці детальніше. Потиличний індекс (ПІ), який указує на співвідношення випадків вормієвих кісток потилично-соскоподібного шва й одночасно лямбдоподібного шва становить у ямної спільноти 16,6\% і, таким чином, у досліджуваної групи малий. Своєю чергою, у катакомбної групи він уже підвищений - 26,0\% (Табл. 1). Як ми знаємо, ПІ має тенденцію сильно варіювати у межах споріднених груп ${ }^{60}$, тому не потрібно сильно акцентувати на цій ознаці саме у даному разі.

Клиноподібний верхньощелепний шов (КВШ) у вибірці ямної культури з показником у 71,0\% виявився підвищеним і не набагато відрізняється від катакомбної культури з території України, де ми зафіксували 61,8\%. Ця ознака суттєво відмінна від груп Азово-Каспійських степів (Табл. 2). Як відомо, КВШ в цілому частіше трапляється в європеоїдів, ніж у монголоїдів61.

Частота підорбітного візерунку типу II (ПОВ-II) у досліджуваних добірках низька (37,3\% - ямна культура та $21,2 \%$ - катакомбна), що робить цю ознаку, в даному

60 Громов А.В. Антропология населения... С. 83.

61 Козинцев А.Г. Этническая краниоскопия... С. 55. 
випадку, дуже цікавою (Табл. 1 та 2). Вона відокремлює групи з території України від серій Азово-Каспійських степів. Низьку частоту О.Г. Козінцев відніс до показників, притаманних південним європеоїдам і східноазійським монголоїдам одночасно. Як нам відомо, у межах європеоїдної та монголоїдної раси й, окрім того, у контактній зоні, О.Г.Козінцев відзначив єдину закономірність: у північних групах ПОВ-II трапляється частіше, ніж у південних ${ }^{62}$. Як виявив А.А. Громов, серед європеоїдних груп відносно низька частота ПОВ-II характерна для серій ямнокатакомбного кола культур, за винятком представників ямно-катакомбної культури Калмикії63. Особливо дослідник виокремив окунівців, низька частота ПОВ-II ставить їх в особливе становище та залишає відкритим питання про унікальність краніоскопічних особливостей окунівської культури серед синхронних популяцій сибірського регіону ${ }^{64}$. Слід зазначити, що групи доби бронзи з території України мають ще менший відсоток ПОВ-II.

Задньовиличний шов (ЗВШ) на черепах двох досліджуваних серій трапляється в однаково малій кількості і не виходить за європеоїдні норми.

Індекс поперечно-піднебінного шва (ІППШ) у досліджуваних групах доби бронзи майже однаковий (63,7\% - ямна культура та 68,0\% - катакомбна) і вкладається у межі, більше характерні для європеоїдів. Оскільки, за даними О.Г. Козінцева, незважене середнє для європеоїдів дорівнює 70,5\%, а для монголоїдів - 49,9\%65.

Можна констатувати, що відсотки надорбітних отворів (HO)66 на черепах із могильників доби бронзи підвищені та наближають їх радше до азійських, а не до європеоїдних серій.

До описаних ознак слід додати метопічний шов (metopic) для інформативності, як це було зроблено з сарматською культурою67. Черепи ямної культури з території України мають його в 7,4\%, своєю чергою, катакомбної культури - в 4,7\%. Таким чином, за наявністю метопічного шва ямна й катакомбна серії потрапляють у зону порівняно невисоких частот (Табл. 1).

Своєрідність краніоскопічного комплексу в досліджуваних двох групах доби бронзи з території України, таким чином, визначається трьома ознаками: низькою частотою ПОВ-ІІ та високою частотою НО та КВШ.

Виявлено дуже слабку відмінність ямної та катакомбної культури з території України (епоха ранньої та середньої бронзи) за двома ознаками. Носії катакомбної культури відрізняються трохи підвищеними відсотками потиличного індексу та заниженими відсотками ПОВ-II (Табл. 1), але такі показники не можна ототожнювати зі зміною населення, на чому наголошувала й C.I. Круц ${ }^{6}$, яка досліджувала населення доби бронзи за даними краніометрії.

При порівнянні відомих на сьогодні серій за даними краніоскопії, відзначено, що носії катакомбної культури вирізняються трохи підвищеними відсотками ПІ, які вищі за притаманні перерахованим серіям Азово-Каспійських степів (Калмикії,

62 Ibid. C. 89.

63 Громов А. В. Антропология населения... С. 84.

64 Ibid. C. 80.

65 Козинцев А.Г. Этническая краниоскопия... С. 110.

66 Томашевич Т.В. Закономерности распределения... С. 119-128.

67 Балабанова М.А. К антропологии населения энеолита - ранней бронзы (по материалам могильников Волгоградской области) // Нижневолжский археологический вестник. 2016. Т. 15. № 1. С. $72-94$.

68 Круц С.И. Позднетрипольские памятники... С. 33. 
Ростовської та Волгоградської обл.), які дослідили А.В. Громов і О.О. Казарницький (епоха ранньої та середньої бронзи) ${ }^{69}$. Встановлено, що на черепах з території України показники КВШ у середньому набагато вищі, а ПОВ-II - трохи нижчі за характерні для груп з території Калмикії, Ростовської та Волгоградської обл., що притаманно південним європеоїдам, особливо це стосується носіїв катакомбної культури (Табл. 1). Тенденцію до зменшення частоти КВШ із Заходу на Схід для більшості серій епох неоліту та бронзи відзначав А.В. Громов ${ }^{70}$, але у нашому випадку ця тенденція дуже виразна. 3 території України зафіксовано в цілому 67,0\% КВШ, тоді як на Сході (катакомбна культура Калмикії) - 24,3\%.

Порівняльний багатовимірний аналіз. Для визначення відносин досліджуваних груп з вибірками Азово-Каспійських степів 71 , а також з ямною та катакомбною культурами Калмикії, андронівською, окунівською, афанасіївською, тагарською72, карасуцівцівською культурами 73 було застосований аналіз ГК за п'ятьма ознакам. ПІ не було включено до аналізу в зв'язку з малою кількістю спостережень у деяких серіях, залучених для порівняння, а також, щоб уникнути впливу штучної деформації, характерної для черепів деяких серій, включених до порівняння за прикладом А.В. Громова74.

У зв'язку з тим, що стаття обмежена в обсягу, ми не порівнюємо групи доби бронзи з території України з неолітом Європи й Азії, але ми вже розпочали досліджувати такі серії: Дереївка, Ясиноватка, Ігренський могильник тощо 75.

Як порівняльний матеріал було використано дані 10 описаних серій. Результати подано у табл. 4 і 5.

Таблиця 4.

Коефіцієнти кореляції між дискретно-варіативними ознаками в серіях епохи бронзи (чоловіки та жінки)

\begin{tabular}{|l|c|c|c|c|c|}
\hline \multicolumn{1}{|c|}{ Ознаки } & КВШ & 3ВШ & ПОВ-II & ІППШ & HO \\
\hline КВШ & - & & & & \\
\hline ЗВШ & $-\mathbf{0 , 5 7 9 *}$ & - & & & \\
\hline ПОВ-II & $-0,491$ & 0,303 & - & & \\
\hline IППШ & $-0,396$ & $\mathbf{0 , 5 4 4} *$ & 0,109 & - & - \\
\hline HO & $-0,343$ & 0,493 & $-0,134$ & $-0,128$ & \\
\hline
\end{tabular}

$* \mathrm{P}<0,05$

Розглянемо міжгрупові зв'язки дискретно-варіативних ознак під час порівняння серій (Табл. 4). Найсильніший зв'язок (більше, ніж 0,5 за абсолютною величиною) об'єднує три ознаки: КВШ, ІППШ і ЗВШ. На рівні близько 0,5 до них

\footnotetext{
69 Громов А.В. Антропология населения... Табл. 11. С. 79-87; Казарницкий А.А. Население азовокаспийских степей в эпоху бронзы (антропологический очерк). Санкт-Петербург: Наука, 2012. C. $163-171$.

70 Громов А.В. Антропология населения... С. 83.

${ }^{71}$ Казарницкий А.А. Население азово-каспийских степей... С. 163-171.

72 Козинцев А.Г. Этническая краниоскопия... С. 55.

73 Громов А.В. Антропология населения... Табл. 11. С. 81-82.

74 Ibid. Табл. 11. C. 85.

75 Потехина И.Д. Население Украины в эпохи неолита и раннего энеолита: по антропологическим данным. Киев: Инст. археологии НАНУ, 1999.
} 
приєднуються ще дві ознаки, які диференціюють групи - НО та ПОВ-II. Таким чином, у цьому аналізі практично всі перераховані та залучені до аналізу ознаки є найбільш диференціювальними расовими ознаками.

Важливими зазвичай вважаються ті ГК, власні числа яких більші за одиницю76. У нашому випадку таких ГК лише дві (Табл. 5).

Таблиця 5.

Коефіцієнти кореляції між вихідними ознаками та значеннями перших трьох ГК для 12 груп (чоловіки й жінки).

\begin{tabular}{|l|c|c|c|}
\hline \multicolumn{1}{|c|}{ Ознаки } & I ГK & II $\mathbf{~} \mathbf{K}$ & III $\mathbf{~} \mathbf{K}$ \\
\hline КВШ & $\mathbf{- 0 , 8 5 8}$ & 0,036 & 0,211 \\
ЗВШ & $\mathbf{0 , 8 8 8}$ & 0,181 & 0,170 \\
ПОВ-II & 0,517 & $-0,535$ & $\mathbf{- 0 , 6 2 5}$ \\
ІППШ & 0,609 & $-0,380$ & $\mathbf{0 , 6 7 5}$ \\
НО & 0,433 & $\mathbf{0 , 8 7 3}$ & $-0,133$ \\
Власне число & 2,350 & 1,226 & 0,937 \\
Частка загальної мінливості, \% & 47,004 & 24,528 & 18,749 \\
\hline
\end{tabular}

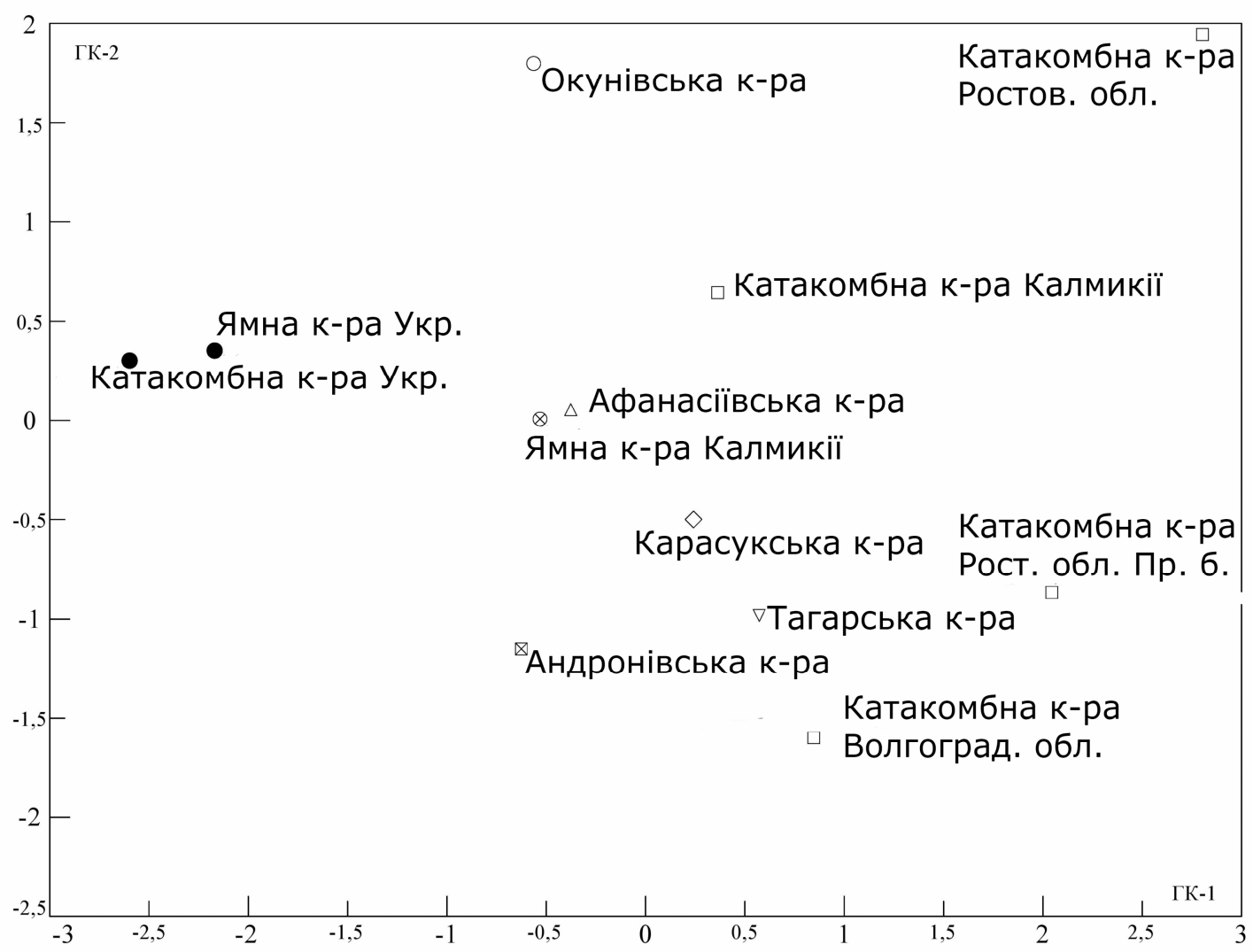

Рис. 1. Розташування 12 краніологічних груп епохи бронзи у просторі I I II ГК.

76 Козинцев А.Г. Этническая краниоскопия... С. 131. 


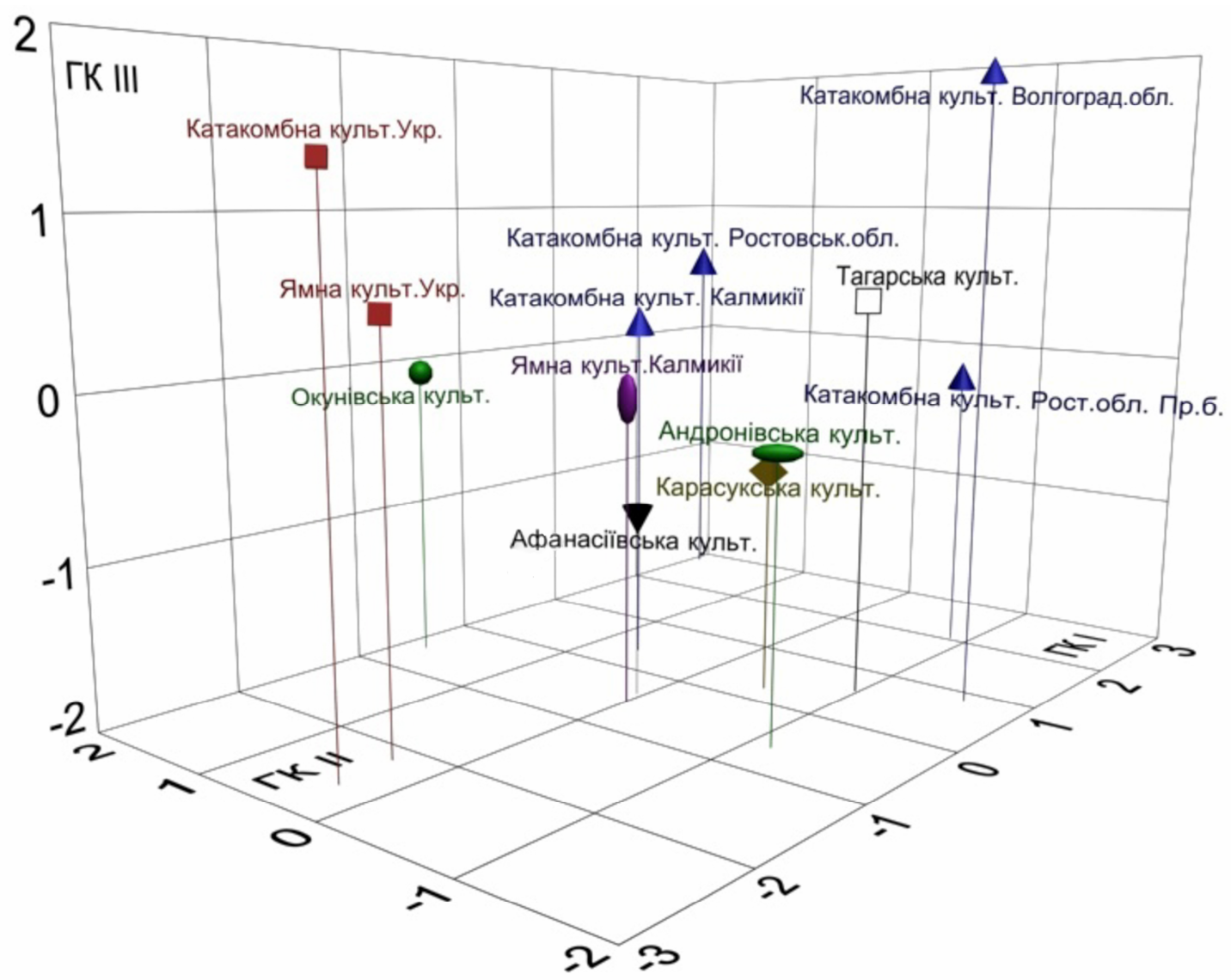

Рис. 2. Розташування 12 краніологічних груп епохи бронзи у тривимірному просторі.

Побудований за першими двома ГК графік (Рис. 1) утворює двомірну проекцію взаємного розташування груп у п'ятимірному просторі з мінімальними можливими викривленнями. Дві досліджувані групи опиняються у лівій центральній частині графіка за рахунок великих від'ємних значень першої ГК $(-2,170)$ для ямної культури та -2,598 - для катакомбної (47,0\% загальної мінливості). Найбільш інформативними ознаками, які роз'єднують групи, виявилися ЗВШ і КВШ (Табл. 5).

За рахунок помірних додатних ознак другої ГК (24,5\% загальної мінливості), також виявлено подібність досліджуваних серій до ямної $(0,353)$ та катакомбної $(0,303)$ культур. Найінформативнішою виявились одна ознака - НО, яка й розмежовує групи, залучені до аналізу (Табл. 5).

За III ГК (18,7\% загальної мінливості) серія ямної культури отримує помірні додатні значення ГК $(0,306)$, а вибірка катакомбної культури - теж додатні, але великі значення даної ГК $(1,289)$. Як ми вже наголошували, враховуючи власні числа, менші за одиницю, можна просто візуально показати розташування досліджуваних груп (Рис. 2) і не наголошувати на такому результаті за ІІІ ГК. Найбільш інформативними ознаками, що роз'єднують групи за III ГК, виявилися ПОВ-II й ІППШ (Табл. 5), що підтверджує й описову характеристику, надану групам на початку статті.

За результатами кластерного аналізу й скоректованою дистанцією Евкліда, досліджувані вибірки потрапляють до окремого кластера й уже на третьому кроці кла- 
стеризації (дистанція 1,070) з 11 (загальна дистанція 4,384), виявляються подібними.

Отже, за даними етнічної краніоскопії, після багатомірного аналізу ГК і кластерного аналізу виявлено значну подібність ямної та катакомбної культур з території України між собою. Тож у добу бронзи в Дніпровському Надпоріжжі, а також на території сучасної Південної та Східної України проживали групи споріднених племен доби бронзи, кордони поширення яких ще слід досліджувати. За даними археології, змішані ознаки деяких поховань породили гіпотезу про генетичний зв'язок між катакомбною та давньоямною культурами. Наявністю так званих «ямних поховань катакомбного типу» обгрунтовували свою схему послідовного перетворення ямної культури на катакомбну А.П. Круглов і Г.В. Подгаєцький⒎ Протилежної думки дотримувався Л.С. Клейн ${ }^{78}$.

Проведений аналіз дає змогу зробити наступні висновки.

1. Своєрідність краніоскопічного комплексу у досліджуваних двох групах доби бронзи з території України, таким чином, визначається трьома ознаками: низькою частотою ПОВ-ІІ та високою частотою НО та КВШ.

2. На черепах з території України в середньому КВШ набагато частіший, ніж у серіях з Волгоградської, Астраханської та Ростовської обл., а ПОВ-II - трохи нижчий у відсотковому значенні, що притаманно південним європеоїдам, особливо це стосується носіїв катакомбної культури. Таким чином, підтверджується висновок С.П. Сегеди стосовно наявності певного компонента південного грацильного одонтологічного типу на черепах із курганів Нижньої Наддніпрянщини та у збірній серії черепів з курганів Північно-Західного Причорномор'я.

3. За даними етнічної краніоскопії виявлено слабку відмінність між ямною та катакомбною культурами (епоха ранньої та середньої бронзи) з території України за двома ознаками з шести. Носії катакомбної культури відрізняються трохи підвищеними відсотками потиличного індексу та заниженими відсотками ПОВ-II, але такі показники не можна ототожнювати зі зміною населення у цілому.

4. За наявністю метопічного шва ямна та катакомбна серії з території України потрапляють у зону порівняно невисоких частот.

5. Після багатомірного аналізу методом ГК і кластерного аналізу, за даними етнічної краніоскопії виявлено значну подібність ямної та катакомбної культур з території України між собою. Це дає підстави зробити висновки про те, що в добу бронзи у Дніпровському Надпоріжжі (Дніпропетровська, Полтавська, Кіровоградська обл.), а також території сучасної Південної України (Запорізької, Херсонської, Миколаївської обл.) та Східної України (Донецької обл.) проживали групи споріднених племен доби бронзи, кордони між якими ще потребують уточнення.

6. Підтверджуються висновки А.П.Круглова, Г.В.Подгаєцького, а також С.Ж. Пустовалова, зроблені за даними археології, про спадкоємність катакомбної та давньоямної культур.

7.У перспективі планується всі досліджені поховання розбити на хронологічні групи та порівняти ці групи між собою, а також із серіями ямної й катакомбної культур різних регіонів Євразії. Також готується порівняння даних груп з вибірками періодів неоліту й енеоліту.

\footnotetext{
77 Круглов А.П., Подгаецкий Г.В. Родовое общество... С. 159-160.

78 Клейн Л.С. 0 так называемых ямных погребениях...
} 


\section{REFERENCES}

Alekseev, V., Debets G. (1964). Kraniometriia. Metodika antropologicheskikh issledovanii [Craniometry. Methods of Anthropological Studies]. Moskva [in Russian].

Artemenko, I. (1978). Osnovni pidsumky i zavdannia arkheolohichnykh doslidzhen v Ukrainskii RSR [Main Results and Tasks of Archaeological Research in Ukrainian SSR]. Arkheolohiia, 26, 3-20 [in Ukrainian].

Artemenko, I. (1987). Kultury pozdnego bronzovogo veka yuzhnoi polosy lesov Evropeiskoi chasti SSSR: sosnitskaia kultura, komarovskaia kultura, bondarikhinskaia kultura [Cultures of Late Bronze Age of Southern Forest Zone in the European Part of USSR: Sosnitsa Culture, Kovariv Culture, Bondarykha Culture]. In Epokha bronzy lesnoi polosy SSSR. Moskva, pp. 106-118 [in Russian].

Artemiev, A. (2011). Antropolohichni materialy z kurhaniv Nyzhnoi techii Psla (za rozkopkamy 20072011 rr.) [Anthropological Materials from Burial Mounds of Lower Psel (According to Excavations of 2007-2011)] In Suprunenko 0.B. \& Sherstiuk V.V. Kurhany Nyzhnoho Prypsillia. Kyiv, pp. 409-420 [in Ukrainian].

Balabanova, M. (2016) K antropologii naseleniia eneolita - rannei bronzy (po materialam mogilnikov Volgogradskoi oblasti) [About the Anthropology of Neolithic - Early Bronze Population (According to Materials of Burial Grounds from Volgograd Region)]. Nizhnevolzhskii arheologicheskii vestnik, 15, 1, 72-94 [in Russian].

Berezanskaia, S. \& Shaposhnikova, 0. (1957). Retsenziia na knigu T.B. Popovoi «Plemena katakombnoi kultury» [Review of the Book by T. Popova «Tribes of Catacomb Culture»]. Sovetskaia arkheologiia, 2, 38 [in Russian].

Berry, A. \& Berry, R. (1967). Epigenetic Variation in the Human Cranium. Journal of Anatomy, 101, 361-379.

Bratchenko, S. (2001). Donetska katakombna kultura rannioho etapu [Donetsk Catacomb Culture of Early Period]. Luhansk [in Ukrainian].

Chernykh, L. \& Daragan, M. (2015). Kurgany epokhi eneolita - bronzy mezhdurechia Bazavluk - Solenaia - Chertomlyk [Eneolithic and Bronze Abe Burial Mounds of the Region Between Bazavluk - Solenaia Chertomlyk Rivers]. Kiev [in Russian].

Danilenko, V. (1959). Arheologicheskie issledovaniia 1956 goda v Chigirinskom raione [Archaeological Research of 1956 in Chyhyryn District]. Kratkie soobshheniia Instituta arkheologii Akademii nauk USSR, 8, 13-21 [in Russian].

Danilenko, V. (1969). Neolit Ukrainy: Glavy drevnei istorii Yugo-Vostochnoi Evropy [Neolith of Ukraine: Chapters of Ancient History of South-Eastern Europe]. Kiev [in Russian].

Danilenko, V. (1974). Eneolit Ukrainy: Etnoistoricheskoe issledovanie [Copper Age of Ukraine: Ethnohistorical Study]. Kiev [in Russian].

Deriabin, V. (2008) Kurs lektsii po mnogomernoi biometrii dlia antropologov [Course of Lectures on Multidimensional Antrhopology for Anthropologists]. Moskva [in Russian].

Dodo, Y., Ishida, H. (1987). Incidences of Nonmetric Cranial Variants in Several Population Samples from East Asia and North America. Jinruigaku zasshi. The Journal of the Anthropological Society of Nippon, 95, 2, 161-177.

Dolzhenko, Yu. (2015). Kraniometricheskaia harakteristika muzhskih cherepov iz katakombnykh pogrebenii, issledovannykh Ordzhonikidzevskoi arkheologicheskoi ekspeditsiiei [Craniometrical Characteristic of Male Skulls from Catacomb Graves, Examined by the Archaeological Expedition in Ordzhonikidze] In Chernykh, L., Daragan, M. Kurgany epokhi eneolita-bronzy mezhdurechia Bazavluk - Solenaia - Chertomlyk. Kiev, 521-527 [in Russian].

Dolzhenko, Yu. (2018). Kraniologicheskaia izmenchivost nositelei katakombnoi kultury iz stepnogo Pridneprovia [Craniological variability of the catacomb culture representatives from Steppe Dnipro area]. Scriptorium nostrum, 1 (10), 39-73 [in Russian].

Gerasimova, M. (2011). K voprosu o proiskhozhdenii yamnoi kultury [To the Question about the Origin of Pit Grave Culture]. Vestnik antropologii, 19, 104-111 [in Russian].

Gromov, A. (2002). Antropologiia naseleniia okunevskoi kultury Yuzhnoi Sibiri: Epoha bronzy [Anthropology of the Population of Okunev Culture from Southern Siberia: Bronze Age]. (Candidate's thesis). Sankt-Peterburg [in Russian].

Kazarnitskiy, A. (2011). Kranioskopiia naseleniia Azovo-Kaspiiskikh stepei v epokhi rannei i srednei bronzy [Cranioscopy of Population of Azov-Kaspiy Steppes in Early and Middle Bronze Age]. Vestnik moskovskogo universiteta. Seriia XXIII, (1), 76-83 [in Russian].

Kazarnitskiy, A. (2012). Naselenie Azovo-Kaspiiskikh stepei v epokhu bronzy (antropologicheskii ocherk) [Population of Azov-Kaspiy Steppes in the Bronze Age (Anthropological Essay)]. Sankt-Peterburg [in Russian]. 
Kazarnitskiy, A. (2012). Naselenie epokhi bronzy v stepiakh Severo-Zapadnogo Prikaspiia [Bronze Age Population in the Steppes of Northwestern Region near Kaspiy]. Zapiski Instituta istorii materialnoi kultury, 6, 133-142 [in Russian].

Klein, L. (1961). O tak nazyvaemykh yamnykh pogrebeniiah katakombnogo tipa [About the So-Called Pit Grave Burials of the Catacomb Type]. Sovetskaia arkheologiia, 2, 49-65 [in Russian].

Klein, L. (1962). Katakombnye pamiatniki epokhi bronzy i problema vydeleniia arkheologicheskikh kultur [Catacomb Monuments of Bronze Age and the Problem of the Archaeological Cultures Separation]. Sovetskaia arkheologiia, 2, 26-38 [in Russian].

Klein, L. (1968). Proiskhozhdenie donetskoi katakombnoi kultury [The Origin of Donetsk Catacomb Culture]. (Extended abstract of Candidate's thesis). Leningrad [in Russian]

Klein, L. (1970). K proverke osnovanii gipotezy o geneticheskoi sviazi yamnoi i katakombnoi kultur [To the Verification of the Hypothesis about Genetic Relations between Pit Graves and Catacomb Cultures]. Sovetskaia Arkheologiia, 1, 49-57 [in Russian]

Konduktorova, T. (1973). Antropologiia naseleniia Ukrainy mezolita, neolita i epokhi bronzy [Anthropology of the Population of Mesolithic, Neolithic and Bronze Age Ukraine]. Moskva [in Russian].

Kozintsev, A. (1973). Ispolzovanie diskretno-var'iruiushchikh kraniologicheskikh priznakov pri individualnoi diagnostike [The Use of Discretely-Varying Craniological Features During the Individual Diagnostics]. Voprosy antropologii, 44, 136-141 [in Russian].

Kozintsev, A. (1980). Diskretnye priznaki na cherepakh epokhi bronzy iz Yuzhnoi Sibiri. K problemam metodiki izucheniia kraniologicheskogo polimorfizma [Discrete Features on the Skulls of Bronze Age from Southern Siberia. To the Problems of Research Methodic Related to Craniological Multiformity]. Issledovaniia po paleoantropologii i kraniologii SSSR, 75-99 [in Russian].

Kozintsev, A. (1984). Zadneskulovaia shchel kak rasorazgranichitelnyi priznak [Posterior Zygomatic Fissure as the Race Demarcative Feature]. Voprosy antropologii, 74, 55-61 [in Russian].

Kozintsev, A. (1987). Kranioskopiia i rasovaia klassifikaciia [Cranioscopy and Racial Classification]. Sovetskaia etnografiia, 2, 12-31 [in Russian].

Kozintsev, A. (1988). Etnicheskaia kranioskopiia i rasovaia izmenchivost shvov cherepa sovremennogo cheloveka [Ethnic Cranioscopy: Racial Variability of the Cranial Sutures of Contemporary Man]. Leningrad [in Russian].

Kozintsev, A. (1992). Ethnic Epigenetics: A New Approach. Homo, 43/3, 213-244.

Krivtsova-Grakova, O. (1962). Pogrebeniia bronzovogo veka i predskifskogo vremeni na Nikopolskom kurgannom pole [Bronze Age and Pre-Scythian Burials of Nikopol Burial Mound Field]. Materialy $i$ issledovaniia po arkheologii SSSR: Pamiatniki skifo-sarmatskoi kultury (Vol. 115, pp. 5-55). Moskva [in Russian].

Kruts, S. (1972). Naselenie territorii Ukrainy epokhi medi-bronzy (po antropologicheskim dannym) [Copper and Bronze Ages Population of the Territory of Ukraine (According to Anthropological Data)]. Kiev [in Russian].

Kruts, S. (1977). Pozdnetripolskie pamiatniki Srednego Podneprov'ia [Late Trypolian Sites of Central Dnipro Region]. Kiev [in Russian].

Kruts, S. (1979). K antropologii drevnego naseleniia Zaporozhskoi oblasti [To the Anthropology of Ancient Population of Zaporizhzhia Region]. Paleoantropologicheskie materialy iz mogilnikov Ukrainy, (pp. 3-22). Kiev [in Russian].

Kruts, S. (1984). Paleoantropologicheskie issledovaniia Stepnogo Podneprov'ia (epokha bronzy) [Paleoanthropological Studies in Steppe Dnipro Region (Bronze Age)]. Kiev [in Russian].

Kruglov, A. \& Podgaetskiy, G. (1935). Rodovoe obshhestvo stepei Vostochnoi Evropy [Patrimonial Society of the Eastern European Steppes]. Izvestiia Gosudarstvennoi akademii istorii materialnoi kultury, 119 [in Russian].

Litvinenko, R. (2002). Kultura Babino (mnogovalikovoi keramiki) i problemy bronzovogo veka baseina Dona [Babino (Multi-Cordoned Ware) Culture and the Problems of Bronze Age in Don Basin]. Arkheologicheskie pamiatniki Vostochnoi Evropy, (pp. 76-85). Voronezh [in Russian].

Lytvynenko, R. (2009). Geneza, rozvytok ta istorychna dolia kulturnoho kola Babyne [Genezis, Development and Historical Fate of Cultural Circle Babyne]. Materialy ta doslidzhennia z arkheolohii Skhidnoi Ukrainy, 9, 44-90 [in Ukrainian].

Lytvynenko, R. (2019). Babynski kultury Ukrainskoho Livoberezhnoho Lisostepu [Babyn Cultures from the Left-Bank Ukrainian Steppe]. Ukrainska arkheolohiia: zdobutky, suchasnyi stan ta perspektyvy, (pp. 195-198). Sumy [in Ukrainian].

Martin, R. (1928). Lehrbuch der Anthropologie in Systematischer Darstellung mit Besonderer 
Berücksichtigung der Anthropologischen Methoden für Studierende, Ärtze und Forschungsreisende, 2, Jena.

Mozolevskiy, B. (1908). Skifskie kurgany v okrestnostiakh g. Ordzhonikidze na Dnepropetrovshhine. Skifiia i Kavkaz [Scythian Burial Mounds on the Outskirts of Ordzhonikidze in Dnipropetrovsk Region. Scythia and Caucasus]. Kiev [in Russian].

Polin, S., Chernykh, L., Daragan, M. \& Razumov, S. (2008). Issledovaniia kurganov epokhi bronzy i skifskogo perioda u g. Ordzhonikidze (Ukraina) v 2007g. [Examination of the BronzeAge and Scythian Period Near Ordzhonikidze (Ukraine) in 2007]. Revista Arheologica, IV, 1, 135-145 [in Russian].

Popova, T. (1955). Plemena katakombnoi kultury [Tribes of Catacomb Culture]. Moskva [in Russian].

Popova, T. (1955). Etapy razvitiia katakombnoi kultury [Stages of Development of Catacomb Culture]. Sovetskaia Arkheologiia, 22, 41-47 [in Russian].

Potekhina, I. (1999). Naselenie Ukrainy $v$ epokhi neolita i rannego eneolita: po antropologicheskim dannym [Neolithic and Early Eneolithic Population of Ukraine: According to Anthropological Data]. Kiev [in Russian].

Seheda, S. (2001). Antropolohichnyi sklad ukrainskoho narodu: etnohenetychnyi aspekt [Anthropological Compound of Ukrainian People: Ethnogenetic Aspect]. Kyiv [in Ukrainian].

Segeda, S. (1990). Drevneishie obshhnosti zemledeltsev i skotovodov Severnogo Prichernomoria 5 tys. do n. ery [The Most Ancient Features of Tillers and Cattlemen of Northern Black Sea Coast in the $5^{\text {th }}$ Mill. B. C.]. Abstracts of Papers'90: Materialy mezhdunarodnoi konferentsii (Kishinev, 10-14 dekabria 1990 g.), (pp. 97-99). Kiev [in Russian].

Segeda, S. (1991). Pozdneiamnoe naselenie Severo-Zapadnogo Prichernomor'ia po antropologicheskim dannym [Late Pit Graves Population of Northwestern Black Sea Coast According to Anthropological Data]. Sankt-Peterburg [in Russian].

Shaposhnikova, 0. (1962). Poseleniia yamnoi kultury na Nizhnem Podneprovie [Settlements of Pit Grave Culture in Lower Dnipro Region]. (Extended abstract of Candidate's thesis). Moskva [in Russian].

Suprunenko, 0. (2006). Kurhany mizh ss. Dukanychi ta Solontsi na nyzhnomu Psli [Burial Mounds between Dukanychi and Solontsi Villages on the Lower Psel]. Kyiv-Poltava [in Ukrainian].

Suprunenko, 0. \& Sherstiuk, V.V. (2011). Kurhany Nyzhnoho Prypsillia [Burial Mounds of Lower Psel Region]. Kyiv [in Ukrainian].

Telehin, D. (1961). Vasylivskyi tretii nekropol v Nadporizhzhi [The 3rd Vasylivka Necropolis in Nadporizhzhia]. Arkheolohiia, XIII, 3-19 [in Ukrainian].

Tomashevich, T. (1988). Zakonomernosti raspredeleniia chastot nadglaznichnykh kanalov cherepa cheloveka [Regularities of Allocation of the Frequencies of Infraorbital Canals on Human Skulls]. Voprosy antropologii, 80, 119-128 [in Russian].

Zinevich, G. (1967). Ocherki paleoantropologii Ukrainy [Essays on the Paleoanthropology of Ukraine]. Kiev [in Russian].

Zalizniak, L. (Ed.) (2005). Arkheolohiia Ukrainy [Anthropology of Ukraine]. Kyiv [in Ukrainian].

Zinevych, H. \& Kruts, S. (1968). Antropolohichna kharakterystyka davnoho naselennia terytorii Ukrainy (za materialamy ekspedytsii 1961-1963 rr.) [Anthropological Characteristic of Ancient Population of Ukrainian Territory (According to the Materials from the Expedition in 1961-1963)]. Kyiv [in Ukrainian].

Zubov, A. (1968). Odontologiia. Metodika antropologicheskikh issledovanii [Odontology. Methodic of Anthropological Studies]. Moskva [in Russian].

Zubov, A. (1973). Odontoglifika (Zakonomernosti variatsii mikroreliefa koronki moliarov cheloveka) [Odontoglipics (Regularities of the Variety of Microrelief of Human Molar Crowns)]. Moskva [in Russian].

\section{Yuriy Dolzhenko}

(Institute of Archaeology National Academy of Sciences of Ukraine, Kyiv, Ukraine)

e-mail: yuriy_dolzhenko@ukr.net

ORCID: https://orcid.org/0000-0001-9807-2835

\section{CRANIOSCOPIC CHARACTERISTICS OF UKRAINE PIT AND CATACOMB CULTURES REPRESENTATIVES}

The discrete-variable features on the skulls of Early and Middle Bronze Age humans (pit 
and catacomb cultures) from the territory of modern Ukraine are studied in the paper. The author has analyzed 253 skulls.

A cranioscopic program, which includes six traits, was used for the study. Concerning them, in the study of the occipital index, posttemporal raphe, infraorbital pattern type II, index of the transverse palatine raphe, and supraorbital foramina, data were taken without regard to sex, and for sphenoidal maxillary raphe, the half amount of data of men and women were determined. To compare groups on discrete-variable features, the computer programs for performing multidimensional analysis, created by B.O. and O.H. Kozintsev in 1991 were used, as well as the method of principal components analysis (PCA), one of the models of factor analysis. The analysis was employed using the statistical program PCCOMP, which performs a principal component analysis and solves the inverse factor problem: finds the value of each component for each object. The PCDENDU program performs a clustering analysis of the matrix of Euclidean distances by an unweighted pair-group method (UPGMA method). Dendrograms were drawn separately using Excel, Corel Draw-11, and 3D Max programs based on the analysis of the PCA method, using the centroid coordinates of the first two vectors. Previously, in order to stabilize the dispersion, the frequencies were converted to radians using the author program created in 1996 by anthropologist, candidate of Historical Sciences A.V. Hromov.

The weak difference between a pit and catacomb cultures (end of the 3rd - the beginning of the $2^{\text {nd }}$ millennium BCE) from the territory of Ukraine is shown on two traits of six (Early and Middle Bronze Age). The representatives of catacomb culture are characterized by slightly higher percentages of the occipital index and lower percentages of the infraorbital pattern type II, but such indicators can not be equated with population change in general. The significant similarity of pit and catacomb cultures from the territory of Ukraine gives grounds to conclude that in Early and Middle Bronze Age Dnipro Nadporizhzhya (Dnipropetrovsk, Poltava, Kirovohrad Regions), as well as modern South (Zaporizhzhya, Kherson, Mykolaiv Regions) and Eastern (Donetsk Region) Ukraine regions were inhabited by groups of related tribes, the boundaries of whose settlement has yet to be clarified. It has also been found out that, in the presence of a metopic suture, pit and catacomb cultures from the territory of Ukraine belong to the zone of relatively low occurrences.

Keywords: pit culture, catacomb culture, burial, skull, cranioscopy 